\title{
Istotność marginesu, czyli wyparte wątki w historiografii Żydów i studiów żydowskich w Polsce. Uwagi wokół polskiego wydania książki Mordechaja Canina Przez ruiny i zgliszcza*
}

Mordechaj Canin, Przez ruiny i zgliszcza. Podróż po stu zgładzonych gminach żdowskich $w$ Polsce, thum. Monika Adamczyk-Garbowska, Wydawnictwo Nisza, Warszawa 2018, ss. 526.

\section{Wstęp}

Pierwsze polskie wydanie napisanej w jidysz i opublikowanej po raz pierwszy w Tel Awiwie w 1952 r. relacji z kilku odbytych w latach 1946-1947 podróży do Polski Mordechaja Canina ukazało w tłumaczeniu i drobiazgowej redakcji Moniki Adamczyk-Garbowskiej. Głównym tematem tego reportażu jest Polska - jej materialny, społeczny i duchowy krajobraz po Zagładzie, a także rozliczenie się z nią i Polakami przez dawnego jej mieszkańca i ich sąsiada. Co oczywiste, temat ten zdominował również dyskusje wokół polskiego wydania książki ${ }^{1}$. Jest to zrozumiałe, tym bardziej

* Materiały wykorzystane $\mathrm{w}$ tym tekście zebrano w wyniku projektu badawczego „Inclusion of Jewish Citizens in Postwar Czechoslovak and Polish Societies” (projekt nr 16-01775Y) finansowanego przez Czeską Fundację Naukową (Czech Science Foundation). Chciałbym podziękować dr Karolinie Szymaniak za wiele cennych uwag do pierwszej wersji tego tekstu.

${ }^{1}$ Zob. np. Piotr Kieżun, Skarga i oskarżenie. O ksiażce „Przez ruiny i zgliszcza” Mordechaja Canina, „Kultura Liberalna” 525 (2019), nr 4, https://kulturaliberalna.pl/2019/01/29/ piotr-kiezun-recenzja-mordechaj-canin-przez-ruiny-zgliszcza/ [dostęp: 11 maja 2019]; Anna Bikont, To, co Gross pokazat Polakom w „Sasiadach”, żydowski reporter opisat już w 1947 r. Zobaczyt „te same wrogie twarze ludzi w ubraniach Żydów”, „Książki. Magazyn do czytania” 
że stosunek Polaków do Żydów, zarówno w trakcie II wojny światowej, jak i zaraz po niej, jest bodajże jedynym problemem, z którego powodu historia żydowska przebija się i cyklicznie zajmuje centralne miejsce w polskiej debacie publicznej.

W pierwszej części niniejszego tekstu, omawiając najważniejsze treści i cechy książki Canina, zajmę się głównym jej problemem - Zagładą, zniszczeniem cywilizacji żydowskiej na ziemiach polskich, pozostałą po niej pustką i stosunkiem Polaków do Zagłady. W drugiej części chciałbym zwrócić uwagę na umykające obecnej debacie, a także historiografii i studiom żydowskim w Polsce, inne treści tego reportażu i potencjał, jaki moim zdaniem mają one dla przyszłych badaczy historii świata żydowskiego po Zagładzie. Potencjał ten tworzą ewolucja żydowskiej pamięci narodowej, jej rosnący etnocentryczny charakter, zwłaszcza w odniesieniu do dziejów Żydów w Europie Środkowo-Wschodniej, domknięcie procesu „rozwodu” nowych centrów cywilizacji żydowskiej z tą częścią Europy, wreszcie - mit kresu historii Żydów w Polsce po Zagładzie.

\section{Krajobraz Zagłady}

Canin odwiedził Polskę kilka razy w latach 1946 i 1947 jako korespondent najważniejszego amerykańskiego jidyszowego dziennika - lewicowego „Forwerts”. Przez ruiny i zgliszcza jest jednym z kilku napisanych i wydanych jeszcze w latach czterdziestych reportaży („,trawelogów”), których autorami byli głównie dawni Żydzi polscy odwiedzający po 1945 r. miejsce swojego urodzenia, próbujący zmierzyć się z jego krajobrazem po Zagładzie i opisać go swoim amerykańskim, palestyńsko-izraelskim i zachodnioeuropejskim czytelnikom².

(13 listopada 2018), http://wyborcza.pl/ksiazki/7,154165,24042120,to-co-gross-pokazal-polakom-w-sasiadach-zydowski-reporter.html [dostęp: 11 maja 2019]; Roma Sendyka, To, co było, „Dwutygodnik” 255 (2019), nr 5, https://www.dwutygodnik.com/artykul/8259-to-co-bylo.html?fbclid=IwAR23O0njAg6dL0EtVthGEy-FWtCnOXsUe41yZCt27iiMwA7c YfmE1K7q_5w [dostęp: 21 maja 2019].

2 Joseph Tenenbaum, In Search of a Lost People: The Old and New Poland, New York 1948; Szmuel Lejb Sznajderman, Cwiszn szrek un hofenung (a rajze iber dem najem Pojln), Buenos Aires 1947 (wydanie angielskie: Between Fear and Hope, New York 1947); Chaim Szoszkes, Pojln-1946 (ajndrukn fun a rajze), Buenos Aires 1946; Jankew Pat, Asz un fajer. Iber di hurwes fun Pojln, New York 1946 (wydanie angielskie: Jacob Pat, Ashes and Fire, New York 1947); Mosze Szulsztajn, Cwiszn ruinen un rusztowanies (fun a rajze in Pojln), Paris 1949; Samuel Leo Wohl, Majn rajze kejn Warsze, New York 1947; Szimon Samet, Be-woi le-mochorat. Massa le Polin-1946, Tel Aviv 1946. Na temat powrotów opisywanych w księgach pamięci gmin żydowskich, w innych relacjach literackich i dokumentach osobistych zob. 
Znakomity, staranny przekład polski książki Canina jest poprzedzony przemyślanym wstępem Moniki Adamczyk-Garbowskiej przybliżającym czytelnikowi kontekst powstania i kluczową dla treści reportaży biografię autora. Drugi z tekstów wstępnych, autorstwa Łukasza Krzyżanowskiego, w empatyczny sposób przedstawia historyczny i emocjonalny kontekst powrotu ocalałych, czyli - po prostu - Żydów polskich, do dawnych miejsc zamieszkania.

Jak pisze we wstępie Adamczyk-Garbowska, książka Canina to przede wszystkim ,jeremiada”, „tren prozą” poświęcony nie tylko zamordowanej w trakcie Zagłady społeczności, lecz również końcowi wielowiekowej, wyjątkowej cywilizacji Żydów polskich. Jest to też reportaż, elegia, requiem, a miejscami również sensacyjna powieść podróżnicza. Pod względem literackim dzieło Canina zdaje się przewyższać inne, wymienione tu utwory tego typu, łącząc w sobie różne rejestry i różnorodne stylistyki, np. jidyszowego, świeckiego reportażu, socjalistycznej, narodowej retoryki bundowskiej, literackiego modernizmu, lecz także fraz, symboli i zwrotów z żydowskiej literatury religijnej

Nawet bardziej niż pozagładową lamentacją dzieło Canina jest oskarżeniem wszystkiego i wszystkich, którzy zostali w Polsce, o współudział w Zagładzie, wrogą wobec niej obojętność, czerpanie z niej korzyści materialnych, negowanie jej moralnego znaczenia. Autor bez ogródek, bez łagodzących form i niuansów, oskarża Polaków jako naród i społeczeństwo, nowe komunistyczne elity państwa, a nawet powojennych liderów

Monika Adamczyk-Garbowska, Patterns of Return: Survivors' Postwar Journeys to Poland, Ina Levine Annual Lecture, 15 February 2007, Washington 2007; Monika Stępień, Miasto opowiedziane. Powojenny Kraków w świetle żydowskiej literatury dokumentu osobistego, Kraków-Budapeszt 2018.

${ }^{3}$ Czytając pierwotną wersję tego tekstu, Karolina Szymaniak zwróciła uwagę na interesujący fakt, że podczas gdy „klasyczny” modernizm literatury jidysz dość często przejmował i przetwarzał symbolikę tradycyjno-religijną, pisany po Zagładzie tekst Canina dokonuje jakby czegoś innego. We wstępie do książki Canin nie przetwarza tradycyjnej teologii religijnej i teleologii katastrofy, lecz wydaje się posługiwać nią wprost, obok instrumentarium świeckiego. Tym samym odnosimy wrażenie, że autor nie tyle przetworzył tradycyjne instrumentarium, ile je podniósł i zrównał z instrumentarium świeckim. Zob. Mordechaj Canin, Przez ruiny i zgliszcza. Podróż po stu zgładzonych gminach żydowskich $w$ Polsce, Warszawa 2018, s. 35-37; zob. też w szczególności oryginalne jidyszowe wydanie tej książki: Iber sztejn un sztok. Masa al pnei mea kehilles nachrawos be Polin, Tel Aviv 1952, s. 5-6. Należy zauważyć, że ani książka Canina, ani wymienione wyżej reportaże z Polski po Zagładzie nie zostały wspomniane w monumentalnej monografii Davida Roskiesa omawiającej żydowskie reakcje literackie na katastrofy dziejowe. Zob. David G. Roskies, Against the Apocalypse: Responses to Catastrophe in Modern Jewish Culture, Syracuse 1999. Temat związku powojennych reportaży z religijną i świecką żydowską tradycją literacką ciągle czeka na swoich badaczy. 
polskiej społeczności żydowskiej. Wstrząsające wrażenie robią odnoszące się niemal do każdego miejsca, o którym pisze, przykłady bezpośredniego udziału ludności polskiej w mordowaniu Żydów ${ }^{4}$ Najprawdopodobniej już w roku 1947, a na pewno w 1952, Canin korzystał z materiałów zbieranych bezpośrednio po wojnie przez Żydowską Komisję Historyczną i był świadom skali antyżydowskich pogromów na Podlasiu latem 1941 r. Prawie dwadzieścia lat przed ukazaniem się artykułu Szymona Datnera, oprócz Jedwabnego - dziś powszechnie znanego za sprawą Jana Tomasza Grossa, Canin opisał przypadki podobnych zdarzeń w Radziłowie, Szczuczynie, Grajewie, Wasilkowie, Tykocinie i innych miejscowościach ${ }^{5}$.

Przez ruiny $i$ zgliszcza to także drobiazgowy zapis wszelkiego rodzaju rabunku, zarówno przed Zagładą, jak i po niej, przywłaszczania mienia pożydowskiego i zacierania wszelkich śladów żydowskiej obecności. Canin pisze o niszczeniu murów synagog w poszukiwaniu ukrytych w nich kosztowności, o macewach używanych do brukowania dróg, o bębnach, torbach, a nawet wkładkach do butów powstających ze zwojów Tory. Opisuje dwory cadyków zamienione w siedziby spółdzielni chłopskich, żydowskie szyldy sklepów przemalowane na polskie, dewastację cmentarzy żydowskich, wreszcie tzw. gorączkę złota i walki pomiędzy chłopami z okalających Treblinkę wsi o prawo do szukania złota w popiołach osób tam zgładzonych $^{6}$. Canin skrzętnie odnotowywał zasłyszane rozmowy i komentarze mieszkańców polskiej prowincji wyrażające zadowolenie z zagłady żydowskich sąsiadów lub zupełną obojętność wobec tych wydarzeń, opisywał również mordy na Żydach dokonane już po wojnie ${ }^{7}$. O tolerowanie tego lub wynikające z różnych kalkulacji przymykanie oka na to wszystko oskarżał nie tylko polskie społeczeństwo, polską inteligencję, lecz również zdominowane przez komunistów władze, a nawet nowe żydowskie elity powojennej Polski.

${ }^{4}$ Zob. np. Canin, Przez ruiny i zgliszcza..., s. 68, 135, 190, 241, 257, 266, 286, 302.

5 Tamże, s. 267-268. Zob. też Szymon Datner, Eksterminacja ludności żydowskiej w Okręgu Białostockim, „Biuletyn Żydowskiego Instytutu Historycznego” (1966), nr 60, s. 3-50; Jan Tomasz Gross, Sąsiedzi. Historia zagłady żydowskiego miasteczka, Sejny 2000; Paweł Machcewicz, Wokót Jedwabnego, [w:] Wokót Jedwabnego, t. 1: Studia, red. Paweł Machcewicz, Krzysztof Persak, Warszawa 2002, s. 9-63.

${ }^{6}$ Canin, Przez ruiny i zgliszcza ..., s. 67, 74, 75, 88, 111, 113, 132, 235, 290. Zob. też Martyna Rusiniak, Obóz zagłady Treblinka II w pamięci społecznej (1943-1989), Warszawa 2008; Jan Tomasz Gross, Irena Grudzińska-Gross, Złote żniwa. Rzecz o tym, co się działo na obrzeżach zagłady Żydów, Kraków 2011.

7 Canin, Przez ruiny i zgliszcza ..., s. 197, 201, 236-237, 242-243, 253, 314, 356. 
Zwłaszcza pierwszy z opisanych wyżej wątków, tzn. postawy Polaków wobec Zagłady, zwrócił szczególną uwagę czytelników i to na nim skupiła się niemal cała dyskusja wokół tej książki. Rozumienie pobudek bezkompromisowości Canina, przyczyn braku empatii dla czegokolwiek i kogokolwiek w powojennej Polsce, nie może jednak zwalniać od ostrożności i krytycznego podejścia. Jak się wydaje, dla autora książki Przez ruiny i zgliszcza mniej istotna była faktograficzna ścisłość, natomiast dużo bardziej - ekspresyjna i mitotwórcza funkcja jego tekstu. Nie ulega wątpliwości - potwierdza to ogromny materiał źródłowy i pokaźna literatura naukowa - że wiele opisanych przez Canina przypadków współudziału Polaków w Zagładzie, obojętności wobec tragedii Żydów, grabieży żydowskiego i pożydowskiego mienia czy wojennego i powojennego antysemityzmu miało miejsce. Jednocześnie jednak próba wykorzystania fragmentów dzieła jako dowodu źródłowego wymaga krytycznej weryfikacji, skonfrontowania z innymi dokumentami. Książka bowiem nie jest kroniką, lecz właśnie elegią, requiem, pełnym osobistego bólu i żalu oskarżeniem.

Canin wprowadzał w błąd wielu swoich polskich rozmówców, a być może czasem wręcz nimi manipulował, podając się w odwiedzanych miejscowościach za brytyjskiego dziennikarza kaleczącego język polski (w rzeczywistości posługiwał się nim doskonale). Jego głównym celem nie było poinformowanie swoich czytelników, lecz ich ukształtowanie, wpłynięcie na nich, wywołanie u nich choć cząstki emocji, których sam doświadczył, konfrontując się z krajobrazem Zagłady. Było to dla niego bardziej istotne niż prawdziwość czy też weryfikacja konkretnych faktów. Widzimy to na przykład, gdy czytamy: „Byłem pierwszym i jedynym pisarzem żydowskim, który odbył taką podróż”8. Jak już wspomniano, Canin na pewno nie był ani pierwszym, ani jedynym pisarzem, który odwiedził powojenną Polskę. W przeciwieństwie do wielu innych tekstów tego typu - reportaż Przez ruiny i zgliszcza nie miał na celu zachęcenia zachodnich społeczności żydowskich do angażowania się w pomoc finansową dla polskiej społeczności żydowskiej. Nie znaczy to jednak, że ta wyjściowa pozycja Canina skazywała go na obiektywizm, bezstronność, sprawiała, że jego tekst w większym stopniu opierał się na faktach czy lepiej weryfikował prawdziwość podawanych informacji. Wręcz przeciwnie, Canin pisał to, co najlepiej korespondowało z jego oskarżającą elegią i jej czarno-białym klimatem. Z tego powodu podawał również niesprawdzone lub nieścisłe

8 Tamże, s. 35. 
informacje (co zresztą w wielu miejscach drobiazgowo wychwyciła w przypisach tłumaczka) ${ }^{9}$.

Ta nieścisła, czasem przemilczająca istotne fakty niezgodne z celami Canina, a niekiedy wręcz kontrfaktyczna strona jego tekstu przenosi nas w słabo dotychczas przebadane obszary polskiej i globalnej historii Żydów po Zagładzie.

\section{Pozagładowe marginesy}

Książka Przez ruiny i zgliszcza zaczyna się od rozdziału poświęconego pobytowi Mordechaja Canina w Warszawie. Od stolicy zaczynali pobyt w Polsce również inni żydowscy goście z Zachodu. Jankew Pat poszedł w kierunku getta zaraz po przylocie do Polski w lutym 1946 r., a „nie mogąc rozpoznać nawet jednej ulicy”, zawróci ${ }^{10}$. Kilka miesięcy później to samo przeżył Samuel Leo Wohl, który uciekł z ruin getta ${ }^{11}$. W przeciwieństwie do nich Canin zareagował inaczej na księżycowy krajobraz zniszczonej Warszawy, jej żydowskiej dzielnicy i położonego tam getta. Pisał: „nie mogłem stamtąd odejść, tak jak nie można odejść od grobu, w którym pochowano najbliższych" ${ }^{12}$. Pat, Wohl i inni nabrali siły, by zobaczyć ruiny Warszawy, dopiero wtedy, gdy odwiedzili inne miejsca w kraju, w tym te nieliczne, w których w latach 1946 i 1947 odrodzenie życia żydowskiego napawało jakimś optymizmem. Dla Canina jednak nie miało to znaczenia. W jego książce, będącej elegią nie tylko na miliony zamordowanych, ale i na zamordowaną wraz z nimi cywilizację, te miliony zabitych były najważniejsze.

Przez ruiny i zgliszcza to pomnik tych zabitych, jak i ich cywilizacji. Kompozycja niemal wszystkich rozdziałów powiela nużącą, zamierzoną konstrukcję. Zaczynają się one od często nader drobiazgowych opisów żywotnej społeczności żydowskiej danego miejsca przed Zagładą, następnie zderzonych z przedstawieniem samej Zagłady i pozagładowych ruin, które na własne oczy widział Canin. Świat przedwojenny opisany przez patrzącego na gruzy jego potomka został przez autora świadomie wyidealizowany. W jego wizji staje się światem cudownej żydowskiej autarkii pozbawionej

\footnotetext{
9 Tamże, s. 45, 83.

10 Pat, Ashes and Fire..., s. 7.

11 Wohl, Majn rajze kejn Warsze..., s. 18-19.

12 Canin, Przez ruiny i zgliszcza ..., s. 39.
} 
wewnętrznych konfliktów ${ }^{13}$. Jako przykład posłużyć może cytat: „Łukowscy Żydzi byli soferami. Komuniści, bundyści i syjoniści, rewizjoniści i agudyści, mizrachiści i nawet chasydzi, słynni wyznawcy cadyka z Kocka - wszyscy w Łukowie kaligrafowali zwoje Tory, mezuzy, tefilin"14. W Łukowie ateizująca szkoła CISZO miała spokojnie funkcjonować obok chederu kockich chasydów. Głębokie i dramatyczne konflikty trapiące żydowski świat, nasilające się zwłaszcza w ostatnich dekadach przed Zagładą, Canin sprowadził w swoim dziele do ledwie wspomnianych, nostalgicznych obrazków, rzeczy niegroźnych i niemających po Katastrofie większego znaczenia. Forma tekstu w postaci elegii na zamordowaną cywilizację nakazywała i narzucała tego rodzaju idealizację i nostalgizację przedwojennego świata. Nic więc dziwnego, że Caninowi „po martwej pustyni Getta cmentarz przy Gęsiej wydał się światem życia". To na nim, na cmentarzu, znalazł to, czego nie było za życia, lecz co teraz, budując żydowską pamięć po Zagładzie, powołał - harmonijną autarkię przedwojennej żydowskiej cywilizacji, symbolizowaną przez żydowski cmentarz, na którym zgodnie obok siebie leżeli dawni polityczni, ideowi i społeczni przeciwnicy ${ }^{15}$. Książka Przez ruiny i zgliszcza jest zatem dobitnym przykładem transformacji, jaką przeszedł po Zagładzie Canin i całe jego pokolenie. Transformacji, która tego byłego sympatyka wojująco ateistycznego Bundu doprowadziła nie tylko do pogodzenia się z żydowską tradycją, ale i do uwznioślenia jej jako jednej z najważniejszych narodowo-etnicznych wartości bezpowrotnie utraconego świata. Tego rodzaju świadectwa transformacji są zresztą wspólne dla tekstu Canina i innych tego typu reportaży, a także twórczości literackiej tych, którzy przeżyli Zagładę i opłakiwali utracony w jej wyniku świat.

Podobna idealizacja nie oddaje prawdy o przedzagładowej przeszłości, lecz prawdę o procesach formowania się pozagładowej pamięci o tej przeszłości. Reportaż Przez ruiny i zgliszcza może więc i powinien się stać ważnym źródłem do badań nad formowaniem się tych procesów w nowych centrach światowej cywilizacji żydowskiej po Zagładzie. Model wewnętrznie harmonijnej społeczności żydowskiej, jej kulturowej autarkii w Europie Środkowo-Wschodniej przed Zagładą, zakłóconej jedynie problemami

${ }^{13}$ Należy zwrócić uwagę, że na wielką skalę mit przednowoczesnej, harmonijnej żydowskiej autarkii pojawia się już w okresie międzywojennym, idealizując świat Żydów wschodnioeuropejskich przed I wojną światową. Po II wojnie światowej został on w dużej mierze zapomniany i zastąpiony mitem świata przed Zagładą, co nie zmienia faktu, że ten drugi mit zawierał w sobie wiele elementów mitu pierwszego.

14 Tamże, s. 208.

15 Tamże, s. 49-53. 
zewnętrznymi w postaci antysemickiej wrogości otoczenia, wydaje się do dziś dominować w popularnej świadomości obecnego świata żydowskiego. Wydana w 1952 r. książka Canina należy do ważnych, fundacyjnych tekstów tej pamięci. W studiach nad tym dokumentem fascynujące analizy przynieść by mogło porównanie go z setkami zaczynających powstawać właśnie na przełomie lat czterdziestych i pięćdziesiątych żydowskich ksiąg pamięci, pełnych bardzo podobnych idealizacji ${ }^{16}$.

W książce Canina ideał przedwojennego świata żydowskiego w prawie każdym rozdziale zderzony został z pozagładową pustką. $\mathrm{O}$ ile nie może dziwić, że jako realnie „puste” jawią się Caninowi całkowicie zburzona warszawska dzielnica północna czy lubelska dzielnica za żelazną bramą, o tyle do zastanowienia zmusza snuty przezeń obraz pustki niemal wszystkich innych opisywanych miejsc. Relację z wizyty w Górze Kalwarii poprzedził obrazem wzniosłości przedwojennego chasydyzmu gerskiego; następnie napisał:

Przyjechałem teraz na stację grójeckiej kolejki w Warszawie, zobaczyłem, kto kupuje bilety do Góry Kalwarii, i poczułem, jak wielkie nieszczęście spotkało polskich Żydów. Chłopki z konwaliami w ręku, chłopi z workami - oto „towarzystwo” jeżdżące dziś do Góry Kalwarii1 ${ }^{17}$.

Pełna nowych, chłopskich mieszkańców Góra Kalwaria, tak jak dziesiątki innych odwiedzanych przez Canina miejscowości, była dla niego pusta, ponieważ nie znajdował w niej Żydów, a na ich miejsce przybyli ci, których uznawał za zaprzeczenie cywilizacji żydowskiej.

Przez ruiny i zgliszcza to ważne i słusznie wykorzystywane źródło w badaniach nad powojennym antysemityzmem. Jednakże powinno się je również badać jako fascynujący zapis pewnego „długiego trwania” wzorów żydowskiego postrzegania społeczeństwa polskiego, jego postfeudalnej struktury i największej liczebnie klasy - chłopów. Wzorce te, sięgające korzeniami jeszcze Rzeczypospolitej Obojga Narodów, uległy daleko idącym

${ }^{16}$ Zob. wyczerpującą bibliografię ksiąg pamięci: Księgi pamięci gmin żydowskich. Bibliografia. Jewish Memorial Books: A Bibliography, red. Adam Kopciowski, Lublin 2008; oryginały większości ksiąg pamięci dostępne są na stronie internetowej: https://digitalcollections. nypl.org/collections/yizkor-book-collection\#/?tab=navigation [dostęp: 11 maja 2019]. Setki tłumaczeń pokaźnych fragmentów ksiąg pamięci dostępne są na stronie internetowej: https://www.jewishgen.org/yizkor/translations.html [dostęp: 11 maja 2019]; Zob. też: Tam byt kiedyś mój dom... Księgi pamięci gmin żydowskich, red. Monika Adamczyk-Garbowska, Adam Kopciowski, Andrzej Trzciński, Lublin 2009; From a Ruined Garden: The Memorial Books of Polish Jewry, red. Jack Kugelmass, Jonathan Boyarin, Bloomington 1998.

17 Zob. Canin, Przez ruiny i zgliszcza..., s. 65. 
przekształceniom w dobie modernizacji i nacjonalizmów w XIX i XX w. To właśnie z chłopami Żydzi, zwłaszcza ci z małych miasteczek, przez setki lat żyli w symbiotycznej, lecz trudnej relacji. Tradycyjnych żydowskich wzorów postrzegania chłopów - elementy tych wzorów obecne są również w tekście Canina (choć zarazem mocno przekształcone pod wpływem doświadczeń międzywojennych i przede wszystkim przez Zagładę) - nie da się sprowadzić do ogólnej i abstrakcyjnej kategorii „goja”. Stosunek autora do chłopów, podobnie jak w przypadku wielu innych przedstawicieli jego pokolenia, jest wyjątkowy i zazwyczaj inny niż do poszlacheckiego inteligenta polskiego. Bez wątpienia cechuje go poczucie wyższości, której imperatyw wykrzyczenia narzucało doświadczenie Zagłady. Canin pisał: „podczas gdy okoliczni [okolice Kosowa Podlaskiego - K.K.] chłopi nawet nie potrafili się podpisać, kosowska gmina żydowska aspirowała do lepszego życia, na wyższym poziomie"18; „Zabłudów nie wygląda dziś jak miasto. Został cofnięty w daleką przeszłość, kiedy Żydzi przynieśli tutaj pierwszą łyżkę i pokazali chłopu, że można nie jeść rękami”"19.

Canin - jidyszysta, choć wychowany w tradycyjnym środowisku żydowskim, podobnie jak wielu innych przedstawicieli jego pokolenia, doskonale znał język polski i żywił ogromną rewerencję dla kultury polskiej. Inaczej zupełnie patrzył na prowincjonalne miasteczka, których nowi, chłopscy mieszkańcy byli dlań zarazem i śmieszni, i straszni, a których obecność była uzurpacją oraz zniszczeniem cywilizacji żydowskiej. Gdy w Lubartowie opisywał „skutki działania wieprzów, które bezlitośnie zryły groby i porozbijały macewy"20, wydaje się, że nie przemawiała przezeń jedynie gorycz Zagłady, lecz także dużo starsze stereotypy na temat chłopskiego brudu, prymitywizmu i barbarzyństwa. Być może niektóre elementy takiej postawy widzimy również w dzisiejszej żydowskiej kulturze popularnej odnoszącej się do Polski i Zagłady ${ }^{21}$. Zapośredniczony i zmieniony przez Zagładę wpływ doświadczeń międzywojennych (i starszych) na formowanie się żydowskiej pamięci po 1945 r., obrazu Polski i polskiego społeczeństwa, wydaje się kolejnym fascynującym, ciągle czekającym studiów, problemem badawczym. Tekst Canina może być w tych badaniach ważnym źródłem.

18 Tamże, s. 233.

19 Tamże, s. 278.

${ }^{20}$ Tamże, s. 133.

${ }_{21}$ Zob. na przykład słynny komiks Arta Spiegelmana, Maus. Opowieść ocalałego (wydanie zbiorcze), Warszawa 2016; występuje tam triada: Żydów obrazują myszy, Niemców - koty, a Polaków - świnie. 
Mitowi pięknej, autarkicznej przedwojennej cywilizacji żydowskiej w książce Canina przeciwstawiony został inny mit - barbarzyństwa cywilizacji chłopskiej, która zniszczyła, zatopiła tę pierwszą. Nie jest przypadkiem, że bodaj najbardziej pełne bólu i resentymentu zdania pojawiają się w rozdziałach dotyczących Podlasia - miejsca, w którym autor dorastał:

Podlascy chłopi, ciemni, prymitywni fanatycy, od lat podżegani przeciwko Żydom, zostali przez Niemców sprowadzeni do poziomu ludzkich bestii. Chociaż w ich chałupach zobaczycie ściany obwieszone ciemnymi obrazami, wizerunkami świętych męczenników, zmienili się w żądne krwi bestie, które nawet jeśli same nie mordowały, to zaspokajały swoje instynkty patrzeniem na morze żydowskiej krwi ${ }^{22}$.

Nawet w kilku antysemickich - lub wręcz przychylnych eksterminacji Żydów - zdaniach, które usłyszał Canin pośród krajobrazu Zagłady, zawiera się najważniejsza, choć nie jedyna przyczyna przesady, z jaką opisuje negatywne nastawienie Polaków do ich dawnych żydowskich sąsiadów, a także obciążania ich zbiorową winą za to, co się stało. Jak wszystkich Żydów polskich szczególnie bolały go czyny i postawy nie tyle Niemców, nazistów, których po wojnie nigdzie już nie widział, ile nieustannie napotykanych dawnych sąsiadów, obok których dorastał, których język znał, a kulturę i symbole uczony był kochać. Krzywda wyrządzona przez „bliskich” Polaków była bardziej bolesna, odczuwalna, zapadała w pamięć może nawet głębiej niż ta wyrządzona przez „obcych” Niemców. Nie jest przypadkiem, że Canin tak silnie odczuwał to wszystko w rodzinnym Sokołowie Podlaskim, „tam, gdzie pierwszy raz zobaczył piękno pól”, tam, gdzie pierwszy raz ojciec próbował go „zaprowadzić do chederu"23. To doświadczenie sprawiało, że Polska dla powojennych Żydów stała się głównie symbolem bólu i utraty. Takie miejsce należało opuścić na zawsze.

Wielkim, trudnym, lecz bardzo ważnym wyzwaniem badawczym byłoby odtworzenie skomplikowanego procesu tego rodzaju esencjonalizacji pamięci żydowskiej o Polsce, które by zarazem uwzględniło wszystkie elementy historii Zagłady, również te najbardziej nieprzyjemne dla polskiej opinii publicznej. Studia nad takim esencjonalnym mitem są potrzebne również dlatego, że pozostawione odłogiem przez krytycznych badaczy, służą różnym współczesnym „kustoszom polskiej pamięci” budującym

${ }^{22}$ Canin, Przez ruiny i zgliszcza ..., s. 227.

23 Tamże, s. 219. 
zupełnie nieprawdziwy obraz żydowskiego „antypolonizmu”, będącego rzekomo symetrycznym odbiciem antysemityzmu. Takie pogłębione studium ewolucji powojennej pamięci żydowskiej o Polsce i Polakach powinno uwzględniać kontekst Zagłady, ale i poprzedzające ją, opisane wyżej, „długie trwanie” wzorów żydowskiej percepcji oraz kształtujące je w XIX i XX w. konteksty peryferyjnej modernizacji (Żydów, Polaków, Ukraińców i innych okolicznych narodów), nacjonalizmu, wreszcie powojenne polityki tożsamości Izraela, żydowskich społeczności Stanów Zjednoczonych i innych centrów diaspory. Fascynującym projektem byłoby zbadanie współczesnych funkcji i emanacji tej pamięci, na przykład sprawdzenie, które z jej wczesnopowojennych treści są obecne w etnocentrycznych wersjach pamięci Zagłady i historii Żydów nauczanych w trakcie większości współczesnych wycieczek do Polski organizowanych przez izraelskie ministerstwo edukacji ${ }^{24}$.

Ponadto reportaż Przez ruiny i zgliszcza może być ważnym tekstem źródłowym dla następnej, jeszcze nienapisanej historii, której nie będzie początkiem, lecz zakończeniem. Chodzi tutaj o fizyczny i świadomościowy stopniowy rozwód świata żydowskiego z di alte hejm (starym domem) - Europą Wschodnią - rozpoczęty pod koniec XIX w. przez wielomilionową emigrację głównie do Stanów Zjednoczonych i syjonizm, pogłębiony największą do czasu Zagłady żydowską katastrofą wywołaną przez I wojnę światową, rosyjskie rewolucje, wojny domowe i konflikty graniczne lat 1917-1923. W procesie tym Europa Wschodnia stawała się coraz bardziej miejscem żydowskiego upadku, niemożliwości życia, kryzysu i zawiedzionych nadziei - miejscem, które należy opuścić, by te nadzieje zrealizować. Nie jest przypadkiem, że tekst Canina - wyraz ostatecznego upadku wiary dawnego bundowca w socjalizm i braterstwo między Żydami a innymi narodami w tej części Europy - koresponduje tak mocno z Churbn Galicje - opisem zagłady żydowskiej Galicji w okresie I wojny światowej, wyrażającym podobne rozczarowanie innego żydowskiego socjalisty, Szina An-skiego ${ }^{25}$. Tym, co łączy Canina z An-skim, jest

${ }^{24} \mathrm{Na}$ ten temat zob. na przykład: Jackie Feldman, Marking the Boundaries of the Enclave: Defining the Israeli Collective through the Poland “Experience”, „Israel Studies” 7 (2002), nr 2, s. 84-114.

${ }_{25}$ Zob. Szymon (Szin) An-ski, Tragedia Żydów galicyjskich w czasie I wojny światowej. Wrażenia i refleksje z podróży po kraju, thum. Krzysztof D. Majus, Przemyśl 2010. Na temat Churbn Galicje jako wyrazu ideowego rozczarowania An-skiego zob.: Marc Caplan, $A$ Disenchanted Elijah: World War I, Conspiracy Theories, and Allegory in S. An-sky's "Destruction of Galicia”, „Polin” 34 (w przygotowaniu). Serdeczne podziękowania dla Marca Caplana za udostępnienie mi nieopublikowanego jeszcze tekstu. Na temat historii „rozwodu” 
niemożność żydowskiego przetrwania w Europie Środkowo-Wschodniej, teleologia żydowskiej nieobecności.

Podczas swojej podróży Canin spotyka też Żydów, którzy zostali w Polsce. Są oni jednak dla niego czymś dziwnym, ich uparta obecność to aberracja, której przygląda się ze zdziwieniem, konsekwentnie odmawiając jej zrozumienia ${ }^{26}$. Jego książka jako jedyna ze wszystkich wymienionych wyżej tego typu dzieł nie zawiera jakiegokolwiek opisu ani nawet świadectwa wizyty autora na Dolnym Śląsku, gdzie w latach 1946-1947 mieszkała połowa obecnych wówczas w Polsce Żydów. W lutym 1947 r. w dolnośląskich komitetach żydowskich zarejestrowanych było 52 tysiące osób $^{27}$. Jak słusznie zauważa we wstępie Monika Adamczyk-Garbowska, najprawdopodobniej wynikało to właśnie z przyjętej koncepcji teleologii „ruin i zgliszcz”28, do której nie pasowały żywotność i niewątpliwe sukcesy odradzającej się społeczności żydowskiej w Polsce, co było widoczne zwłaszcza na Dolnym Śląsku, ale też na przykład w Łodzi, gdzie mieszkała największa w owym czasie populacja żydowska.

Przekonanie o braku przyszłości narodu żydowskiego w Polsce, tak silne w książce Canina, było zrozumiałe i przekonywające dla jej czytelników w 1952 r. Jednakże to wszystko, co wiedział autor w tamtym czasie i czemu narzucił post factum swoistą teleologie, nie było tak oczywiste wtedy, gdy odwiedzał Polskę, w drugiej połowie 1946 i w 1947 r. W przeciwieństwie do dzieła Canina wszystkie wydane wówczas reportaże zawierały rozdziały o miastach i miasteczkach Dolnego Śląska. Ich żydowscy mieszkańcy wcale nie wydawali się autorom tak dziwni i niezrozumiali w swoich próbach pozostania i budowy przyszłości w kraju. Szmuel Lejb Sznajderman, korespondent innej nowojorskiej jidyszowej gazety, „Der Tog / Di Morgen Żurnal” (nie mniej krytycznej wobec polskiej rzeczywistości niż „Forwerts” Canina), nadał rozdziałowi o Dolnym Śląsku tytuł Światło w ciemności. O tym, co tam zobaczył, pisał:

z Europą Wschodnią innych żydowskich nacjonalistów i socjalistów w tym samym okresie zob.: Joshua M. Karlip, The Tragedy of a Generation: The Rise and Fall of Jewish Nationalism in Eastern Europe, Cambridge-London 2013.

${ }^{26}$ Na przykład: Canin zupełnie zignorował bogatą powojenną żydowską twórczość literacką w Polsce, w tym jej rozliczenia z Zagładą. Na ten temat zob.: Magdalena Ruta, Bez Żydów? Literatura jidysz w PRL o Zagładzie, Polsce i komunizmie, Kraków-Budapeszt 2012.

${ }_{27}$ Zob. Bożena Szaynok, Ludność żydowska na Dolnym Ślasku, 1945-1950, Wrocław 2000, s. 103.

${ }^{28}$ Zob. Canin, Przez ruiny i zgliszcza..., s. 16. 
Żydzi mogą tutaj pracować w fabrykach i kopalniach, w rolnictwie i w administracji państwowej. Na Dolnym Śląsku widziałem żydowskie sklepy z żydowskimi nazwiskami na szyldach - co byłoby zupełnie niemożliwe na dawnych polskich terenach. W miasteczkach i miastach Śląska widziałem również żydowskie plakaty na murach, ogłaszające przedstawienia teatralne, koncerty, wykłady, często słyszałem jidysz na ulicach. Na nowych polskich terenach i na Dolnym Śląsku Żydzi czują się bezpieczniej, bardziej w domu, niż kiedykolwiek czuli się w swoich dawnych domach w polskich miastach i miasteczkach, w których się urodzili. Tutaj nie byli podporządkowani swoim dawnym sąsiadom ${ }^{29}$.

Tego rodzaju opinie nie ograniczały się wówczas do dyskursu żydowskiego $^{30}$.

W książce wydanej w szczytowym okresie stalinizmu, kiedy to w latach 1949-1950 zlikwidowano właściwie wszystkie niekomunistyczne instytucje w kraju i zakończono polityczno-kulturowy pluralizm społeczności żydowskiej, Canin zasugerował, że taki bieg wydarzeń był dla niego oczywisty już w 1947 r. Nie jest więc chyba przypadkiem, że szczątkowe odradzanie się społeczności żydowskiej w tym okresie pokazał na przykładzie Górnego Śląska i Zagłębia Dąbrowskiego, a nie miejsc, w których to odradzanie mogłoby podać w wątpliwość teleologię „ruin i zgliszcz”31. Żydom, których spotykał w Polsce, Canin przede wszystkim się dziwił, nie mógł i nie chciał ich zrozumieć. Podczas gdy skrupulatnie podawał liczby dotyczące szczątkowych społeczności żydowskich miast i miasteczek na pozostałych terenach Polski, nie zrobił tego dla Dolnego Śląska czy Łodzi. Wszystko to, co zobaczył w Łodzi - szkoły żydowskie, uczące się w nich dzieci, które recytowały wiersze (w jidysz), żydowskie spółdzielnie, kolonie letnie, ortodoksyjne centrum przy ulicy Zachodniej - przedstawił jako złudny miraż ${ }^{32}$. Gdy przy okazji wizyty w Białymstoku wspomniał o czterystu Żydach zarejestrowanych w miejscowym komitecie, z których część zdecydowała się pozostać, by w tym miejscu odbudować swoje życie, uczynił to jednym, pozbawionym wszelkiego komentarza zdaniem ${ }^{33}$.

${ }^{29}$ Zob. Sznajderman, Between Fear and Hope..., s. 229. Wszystkie przekłady, jeśli nie są oznaczone inaczej, zostały dokonane przez autora artykułu. Ostatnie zdanie tego fragmentu tekstu jest zupełnie inne i dużo mocniejsze w jidyszowym oryginale książki: „Tu nie doświadczają nienawiści swoich starych, dobrych sąsiadów, patrzących ze zdziwieniem na powracających Żydów i gotowych z domową siekierą zabrać się za każdego z nich”. Zob. tenże, Cwiszn szrek un hofenung..., s. 269-270.

${ }^{30}$ Zob. np.: Marguerite Higgins, Lower Silesian Jews Like Life in Poland, „Washington Post" (February 23, 1947), s. B2.

31 Canin, Przez ruiny i zgliszcza ..., s. 438.

32 Tamże, s. 139.

33 Tamże, s. 261. 
Przekaz tego wypowiedzenia był podobny do tego, co napisał w związku z wizytą w Radomiu ${ }^{34}$ :

Teraz w Radomiu mieszka kilkudziesięciu Żydów. Żyd na ulicy sprawia wrażenie, jakby nie był stąd, bo wszystko jest tutaj obce: domy, ulice, nawet mieszkanie, w którym mieszka, jest mu obce, jakby to nie jego ojcowie i dziadowie budowali to miasto, oddając mu wszystkie swoje twórcze siły. Korzenie radomskiej gminy zostały wyrwane. Odłamane gałęzie schną na obcej, wrogiej ziemi ${ }^{35}$.

To wszystko jednak nie znaczy, że w książce nie ma wartościowych obserwacji na temat powojennej społeczności żydowskiej w Polsce. Bodajże najciekawsze jest w niej nie to, co Canin pisał o „żydowskich” Żydach, lecz o tych, którzy publicznie, a czasem i prywatnie ukrywali swoją tożsamość. W jednym z pierwszych rozdziałów - Kol Nidre w Warszawie - zgodnie z zasadą kontrastu obecną w większości tekstów w książce Canin pisze o przedwojennym mieście liczącym 350 tysięcy Żydów i tym obecnym, w którym „zostało dziesięć tysięcy. A z tych dziesięciu tysięcy wielu żyje w przebraniu, niczym w teatrze. Maskują się, nosząc wojskowe mundury i krzyżyki na piersiach"36. Tych ostatnich Canin obserwował przychodzących na Jom Kippur do synagogi Nożyków:

kiedyś na Kol Nidre szli całymi rodzinami, dziś wszyscy są samotni. Niepostrzeżenie wymykają się ze swoich polskich rodzin i jak marrani biegną na modlitwę [...]. Wysocy rangą oficerowie i dygnitarze przykucają, zapalając przyniesione przez siebie świece za dusze ojców i matek, żon i dzieci, którzy zginęli tak okrutną śmiercią. Nie wiadomo kiedy wyjmują spod mundurów i odświętnych ubrań małe modlitewniki. Przyszli stanąć przed Bogiem! ${ }^{37}$.

Wybiórczy i nieempatyczny wobec pozostających w Polsce „żydowskich” Żydów Canin jak chyba nikt inny oddał charakter i tragedię państwowej asymilacji po Zagładzie pod rządami komunistycznymi, doświadczenie tysięcy tych, którzy po 1945 r. na różne sposoby ukrywali swoje korzenie. Jego tekst, krytycznie odczytany i zestawiony z innymi, może się stać źródłem do badań nad tym fascynującym i słabo rozpoznanym problemem powojennej historii Polski ${ }^{38}$. Tamci ludzie, ich dzieci i wnuki

${ }^{34} \mathrm{Na}$ temat powojennych losów żydowskiej społeczności tego miasta zob.: Łukasz Krzyżanowski, Dom, którego nie byto. Powroty ocalałych do powojennego miasta, Wołowiec 2016.

${ }^{35}$ Canin, Przez ruiny i zgliszcza ..., s. 345.

36 Tamże, s. 58.

37 Tamże, s. 59-60.

${ }^{38}$ W czasie oddawania tego tekstu do druku broniona była na Uniwersytecie Warszawskim przynosząca przełom w tym obszarze rozprawa doktorska Ewy Koźmińskiej-Frejlak. 
zostali w Polsce po wyjeździe z niej Canina. Wielu z nich przychodziło na Kol Nidre przez następne nawet kilkadziesiąt lat. Nie wszyscy wyjechali w 1956 czy 1968 r. Niektórzy z czasem zapisali się do Towarzystwa Społeczno-Kulturalnego Żydów w Polsce i na różne sposoby przekazywali dzieciom swoją tożsamość. Dzieje tego grona stanowią ważny element historii Żydów w Polsce po Zagładzie, o którym obecnie zapominamy, wierząc w „cudowne odrodzenie z niczego" żydowskiego świata w Polsce po 1989 r. O ile to drugie jest fenomenem analizowanym i dyskutowanym, również przez naukowców z Polski ${ }^{39}$, o tyle życie bohaterów rozdziału Kol Nidre $w$ Warszawie w czasach komunizmu, zwłaszcza w latach 1968-1989, prawie nie doczekało się studiów, z wyjątkiem tych, które podjęły badaczki ze Stanów Zjednoczonych ${ }^{40}$.

Przez ruiny i zgliszcza jest reportażem pozbawionym niuansów i szarości, książką esencjonalistyczną per se. Jest dziełem nasyconym nieskrywanymi emocjami, których pełne są również obecne debaty o Zagładzie i jej znaczeniu dla współczesnej tożsamości polskiej. Warto na tekst Canina spojrzeć również inaczej - krytycznie i z mniejszymi emocjami - by lepiej i bardziej wielowymiarowo zrozumieć żydowskie doświadczenie Zagłady i wszystkiego, co nastąpiło po niej.

\section{Bibliografia}

\section{1. Źródła archiwalne}

Biblioteka Uniwersytecka w Warszawie, Doktoraty Wydziału Stosowanych Nauk Społecznych i Resocjalizacji (Archiwum): Koźmińska-Frejlak Ewa, Po Zagładzie. Praktyki asymilacyjne Ocalałych jako strategie zadomawiania się w powojennej Polsce 1944-1950. Rozprawa doktorska, Uniwersytet Warszawski, Warszawa 2019.

Zob. Ewa Koźmińska-Frejlak, Po Zagładzie. Praktyki asymilacyjne Ocalałych jako strategie zadomawiania się w powojennej Polsce 1944-1950, rozprawa doktorska, Uniwersytet Warszawski, Warszawa 2019, dostępna w: Biblioteka Uniwersytecka w Warszawie, Doktoraty Wydziału Stosowanych Nauk Społecznych i Resocjalizacji (Archiwum).

${ }^{39}$ Zob. Katka Reszke, Powrót Żyda. Narracje tożsamościowe trzeciego pokolenia Żydów w Polsce po Holocauście, Kraków-Budapeszt 2013; Jan Lorenz, Remaking Jewish Sociality in Contemporary Poland: Haunting Legacies, Global Connections, rozprawa doktorska, School of Social Sciences, University of Manchester, Manchester 2013, dostępna w: The University of Manchester Library.

${ }^{40}$ Zob. Karen Auerbach, The House at Ujazdowskie 16: Jewish Families in Warsaw after the Holocaust, Bloomington 2013; Rachel L. Rothstein, "Small Numbers, Big Presence": Poland, the U.S., and the Power of Jewishness after 1968, rozprawa doktorska, University of Florida, 2015, dostępna w: George A. Smathers Libraries, University of Florida Digital Collections. 
George A. Smathers Libraries, University of Florida Digital Collections: Rothstein Rachel L., "Small Numbers, Big Presence": Poland, the U.S., and the Power of Jewishness after 1968. Rozprawa doktorska, University of Florida, 2015.

The University of Manchester Library: Lorenz Jan, Remaking Jewish Sociality in

Contemporary Poland: Haunting Legacies, Global Connections. Rozprawa doktorska, School of Social Sciences, University of Manchester, Manchester 2013.

\section{2. Źródła opublikowane}

An-ski Szymon (Szin), Tragedia Żydów galicyjskich w czasie I wojny światowej. Wrażenia i refleksje z podróży po kraju, tłum. Krzysztof D. Majus, Przemyśl 2010. Canin Mordechaj, Iber sztejn un sztok. Masa al pnei mea kehilles nachrawos be Polin, Tel Aviv 1952.

Canin Mordechaj, Przez ruiny i zgliszcza. Podróż po stu zgładzonych gminach żydowskich w Polsce, Warszawa 2018.

From a Ruined Garden: The Memorial Books of Polish Jewry, red. Jack Kugelmass, Jonathan Boyarin, Bloomington 1998.

Higgins Marguerite, Lower Silesian Jews Like Life in Poland, „Washington Post” (February 23, 1947).

Księgi pamięci gmin żydowskich. Bibliografia. Jewish Memorial Books: A Bibliography, red. Adam Kopciowski, Lublin 2008.

Pat Jacob, Ashes and Fire, New York 1947.

Pat Jankew, Asz un fajer. Iber di hurwes fun Pojln, New York 1946.

Samet Szimon, Be-woi le-mochorat. Massa le Polin-1946, Tel Aviv 1946.

Spiegelman Art, Maus. Opowieść ocalałego (wydanie zbiorcze), Warszawa 2016. Sznajderman Szmuel Lejb, Between Fear and Hope, New York 1947.

Sznajderman Szmuel Lejb, Cwiszn szrek un hofenung (a rajze iber dem najem Pojln), Buenos Aires 1947.

Szoszkes Chaim, Pojln-1946 (ajndrukn fun a rajze), Buenos Aires 1946.

Szulsztajn Mosze, Cwiszn ruinen un rusztowanies (fun a rajze in Pojln), Paris 1949. Tam byt kiedyś mój dom... Księgi pamięci gmin żydowskich, red. Monika Adamczyk-Garbowska, Adam Kopciowski, Andrzej Trzciński, Lublin 2009.

Tenenbaum Joseph, In Search of a Lost People: The Old and New Poland, New York 1948.

Wohl Samuel Leo, Majn rajze kejn Warsze, New York 1947.

\section{Opracowania}

Adamczyk-Garbowska Monika, Patterns of Return: Survivors' Postwar Journeys to Poland, Ina Levine Annual Lecture, 15 February 2007, Washington 2007.

Auerbach Karen, The House at Ujazdowskie 16: Jewish Families in Warsaw after the Holocaust, Bloomington 2013.

Bikont Anna, To, co Gross pokazat Polakom w „Sasiadach”, żydowski reporter opisat już w 1947 r. Zobaczyt „te same wrogie twarze ludzi w ubraniach Żydów”, „Książki. Magazyn do czytania” (13 listopada 2018), http://wyborcza.pl/ 
ksiazki/7,154165,24042120,to-co-gross-pokazal-polakom-w-sasiadach-zydowski-reporter.html [dostęp: 11 maja 2019].

Caplan Marc, A Disenchanted Elijah: World War I, Conspiracy Theories, and Allegory in S. An-sky's “Destruction of Galicia”, „Polin” 34 (w przygotowaniu).

Datner Szymon, Eksterminacja ludności żydowskiej w Okręgu Białostockim, „Biuletyn Żydowskiego Instytutu Historycznego" (1966), nr 60.

Feldman Jackie, Marking the Boundaries of the Enclave: Defining the Israeli Collective through the Poland "Experience”, „Israel Studies” 7 (2002), nr 2.

Gross Jan Tomasz, Sasiedzi. Historia zagłady żydowskiego miasteczka, Sejny 2000.

Gross Jan Tomasz, Grudzińska-Gross Irena, Złote żniwa. Rzecz o tym, co się działo na obrzeżach zagłady Żydów, Kraków 2011.

Karlip Joshua M., The Tragedy of a Generation: The Rise and Fall of Jewish Nationalism in Eastern Europe, Cambridge-London 2013.

Kieżun Piotr, Skarga i oskarżenie. O książce „Przez ruiny i zgliszcza” Mordechaja Canina, „Kultura Liberalna” 525 (2019), nr 4, https://kulturaliberalna. pl/2019/01/29/piotr-kiezun-recenzja-mordechaj-canin-przez-ruiny-zgliszcza/ [dostęp: 11 maja 2019].

Krzyżanowski Łukasz, Dom, którego nie było. Powroty ocalatych do powojennego miasta, Wołowiec 2016.

Machcewicz Paweł, Wokół Jedwabnego, [w:] Wokót Jedwabnego, t. 1: Studia, red. Paweł Machcewicz, Krzysztof Persak, Warszawa 2002.

Reszke Katka, Powrót Żyda. Narracje tożsamościowe trzeciego pokolenia Żydów w Polsce po Holocauście, Kraków-Budapeszt 2013.

Roskies David G., Against the Apocalypse: Responses to Catastrophe in Modern Jewish Culture, Syracuse 1999.

Rusiniak Martyna, Obóz zagłady Treblinka II w pamięci społecznej (1943-1989), Warszawa 2008.

Ruta Magdalena, Bez Żydów? Literatura jidysz w PRL o Zagładzie, Polsce i komunizmie, Kraków-Budapeszt 2012.

Sendyka Roma, To, co byto, „Dwutygodnik” 255 (2019), nr 5, https://www.dwutygodnik.com/artykul/8259-to-co-bylo.html?fbclid=IwAR23O0njAg6dL0EtVth GEy-FWtCnOXsUe41yZCt27iiMwA7cYfmE1K7q_5w [dostęp: 21 maja 2019]. Stępień Monika, Miasto opowiedziane. Powojenny Kraków w świetle żydowskiej literatury dokumentu osobistego, Kraków-Budapeszt 2018.

Szaynok Bożena, Ludność żydowska na Dolnym Śląsku, 1945-1950, Wrocław 2000.

Kamil Kijek

Uniwersytet Wrocławski kamil.kijek@gmail.com 